\title{
The Chemical Composition of Endotoxin Isolated from Intestinal Strain of Desulfovibrio desulfuricans
}

\author{
Jolanta Lodowska, ${ }^{1}$ Daniel Wolny, ${ }^{2}$ Marzena Jaworska-Kik, ${ }^{2}$ Sławomir Kurkiewicz, ${ }^{3}$ \\ Zofia Dzierżewicz, ${ }^{2}$ and Ludmiła Wȩglarz ${ }^{1}$ \\ ${ }^{1}$ Department of Biochemistry, Faculty of Pharmacy, Medical University of Silesia, Narcyzow 1 street, 41-200 Sosnowiec, Poland \\ ${ }^{2}$ Department of Biopharmacy, Faculty of Pharmacy, Medical University of Silesia, Narcyzow 1 street, 41-200 Sosnowiec, Poland \\ ${ }^{3}$ Department of Instrumental Analysis, Faculty of Pharmacy, Medical University of Silesia, Narcyzow 1 street, 41-200 Sosnowiec, Poland
}

Correspondence should be addressed to Jolanta Lodowska, jlodowska@sum.edu.pl

Received 14 October 2011; Accepted 27 December 2011

Academic Editor: Raúl Rivas

Copyright ( $\odot 2012$ Jolanta Lodowska et al. This is an open access article distributed under the Creative Commons Attribution License, which permits unrestricted use, distribution, and reproduction in any medium, provided the original work is properly cited.

Desulfovibrio desulfuricans anaerobes are constituents of human alimentary tract microflora. There are suggestions that they take part in the pathogenesis of periodontitis and some gastrointestinal inflammatory disorders, such as ulcerative colitis or Crohn's disease. Endotoxin is one of Gram-negative bacteria cellular components that influence these microorganisms pathogenicity. Endotoxin is a lipid-polisaccharide heteropolymer consisting of three elements: lipid A, core oligosaccharide, and O-specific polysaccharide, also called antigen-O. The biological activity of lipopolysaccharide (LPS) is determined by its structure. In this study, we show that rhamnose, fucose, mannose, glucose, galactose, heptose, and 2-keto-3-deoxyoctulosonic acid (Kdo) are constituents of $D$. desulfuricans endotoxin oligosaccharide core and O-antigen. Lipid A of these bacteria LPS is composed of glucosamine disaccharide substituted by 3-acyloxyacyl residues: ester-bound 3-(dodecanoyloxy)tetradecanoic, 3(hexadecanoyloxy)tetradecanoic acid, and amide-bound 3-(tetradecanoyloxy)tetradecanoic acid.

\section{Introduction}

Bacteria of Desulfovibrio desulfuricans species are sulphatereducing Gram-negative rods settling ecosystems devoid of oxygen. However, Desulfovibrio species are capable of growing in the presence of oxygen [1-3]. Abdollahi and Wimpenny [4] stated that some strains of $D$. desulfuricans were able to survive in an aerobic conditions for 24 hours. The tolerance to oxygen can explain the occurrence of Desulfovibrio spp. in blood and infected tissues [2]. These commensal bacteria settle mainly in alimentary tract of human and animals. However, they were also isolated from bile tract of patient with symptoms of sepsis [5], abscesses of abdominal cavity, liver, and brain [6-8] and from inflamed appendix [9]. These microorganisms are considered to take part in the pathogenesis of some large intestine disorders such as ulcerative colitis and Crohn's disease [10, 11]. Desulfovibrio spp. colonizing the tooth surface is implicated in the etiology of periodontal disease $[12,13]$.
One of the factors responsible for the virulence of Gram-negative bacteria is endotoxin, an integral component of their outer membrane. These polymers are characterized by common structure consisting of three regions: polysaccharide $\mathrm{O}$-antigen, oligosaccharide core, and lipid A (Figure 1). Carbohydrate part of LPS is the most structurally heterogenic region, influencing the bacteria virulence. Its loss may cause the decline of microorganism pathogenicity. $\mathrm{O}$-specific part of LPS consists of repeating oligosaccharide units that are characteristic (in respect of their composition and structure) for a given species of microorganism. These units are commonly built of 2 to 6 , and occasionally of 7 or 8 , monosaccharides creating straightor branched-chain oligosaccharide. D-glucose, D-mannose, D-galactose, L-fucose, D- and L-rhamnose are common constituents of $\mathrm{O}$-antigen. Amino sugars in pyranose form such as D-glucosamine, D-mannosamine, D-galactosamine, which may also be $\mathrm{N}$-acetylated ( $\mathrm{N}$-acetyl-D-glucosamine and $\mathrm{N}$-acetyl-D-galactosamine) are frequent components of 


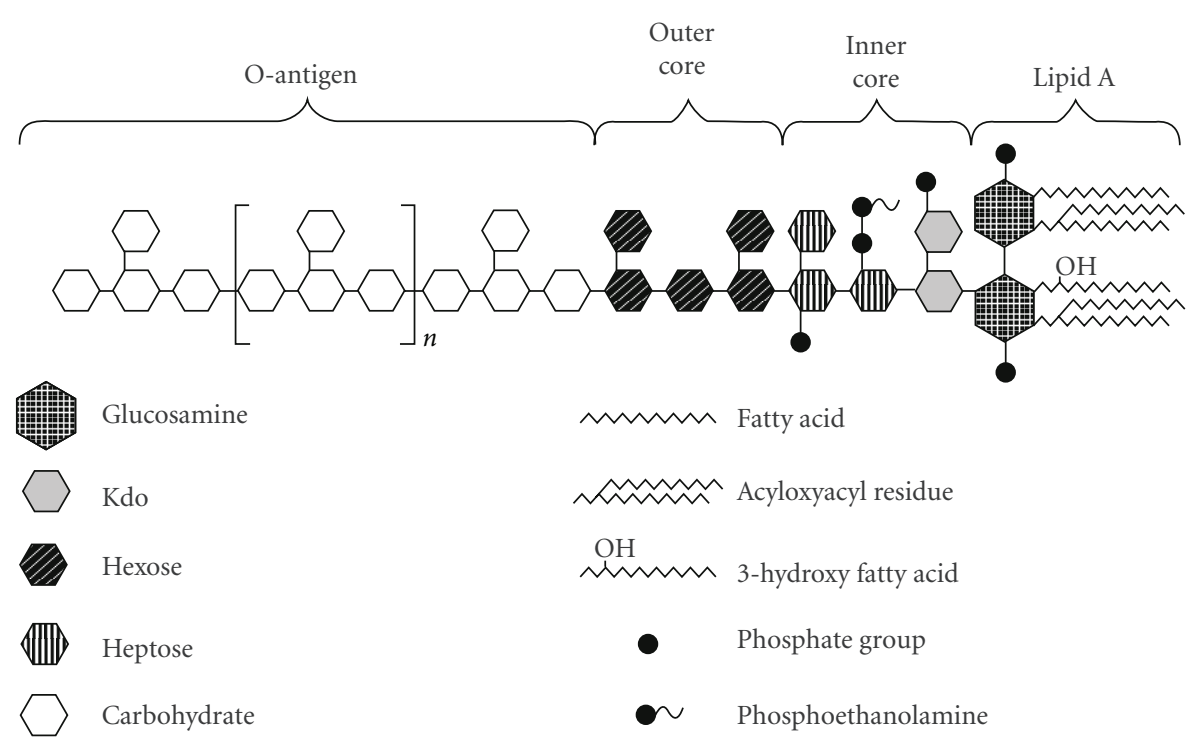

FIgURE 1: The structure of bacterial endotoxin.

O-antigen. 3,6-dideoxyhexoses can be found in polysaccharide part of Enterobacteriaceae endotoxin. Moreover, in the O-specific element of LPS several further carbohydrates were identified, among others: 2 -acetamidine-2,6-dideoxy-Lgalactose (Yersinia ruckeri serotype 01) [14], 3,6-dideoxy-3(R)-3-hydroxybutyramide-D-galactose (Proteus penneri 16) [15], N-acetylmuramic acid (P. penneri 62) [16], and Nacetylneuraminic acid (Salmonella enterica serovar Toucra O48, Hafnia alvei PCM 2386, and Escherichia coli O104) $[17,18]$.

Another part of LPS is oligosaccharide core consist-ing of two regions: the outer-built mostly of hexoses and the inner-composed of heptoses and 2-keto-3-deoxyoctulosonic acid (Kdo).

Kdo links the oligosaccharide core of endotoxin with its hydrophobic part-lipid A, which is composed of Dglucosaminyl-D-glucosamine disaccharide, most commonly substituted by phosphates and ethanolamine or amino-4deoxy-L-arabinose at positions 1 and $4^{\prime}$, and at positions 2 , $3,2^{\prime}$ and $3^{\prime}$ by hydroxy fatty acids. (R)-3-hydroxy fatty acids (most often (R)-3-hydroxytetradecanoic acid) are usually amide-bound to the carbohydrate core of lipid A, whereas (S)-2- or (R)-3-hydroxy fatty acids are ester-bound to glucosamine disaccharide. Hydroxy fatty acids can be acylated by other fatty acids [19]. Glucosamine is not an obvious constituent of carbohydrate core of lipid A. Some bacteria for example, Pseudomonas diminuta and $P$. vesicularis have this core made of two molecules of 2,3-diamino-2,3-dideoxyD-glucose linked by the $\beta(1 \rightarrow 6)$ glycosidic bond [20]. However, this structural modification does not contradict the greatest structural conservatism of lipid A as compared to other LPS parts.

The structure and chemical composition of $D$. desulfuricans LPS are not fully recognized that justifies the effort to elucidate them.

\section{Material and Methods}

2.1. Bacterial Strain and Culture Conditions. The wild strain DV/A of $D$. desulfuricans was isolated from the feces of patient with asiderotic anemia and cholestasis as described previously [21] and cultured under anaerobic conditions in a Postgate's liquid medium containing pyruvate [22].

2.2. Isolation of Bacterial Lipopolysaccharide. LPS was isolated from the cultured bacteria using the method of Westphal et al. [23] and Shynra et al. [24]. Briefly, suspension of bacterial cells was deproteinized with phenol at $68^{\circ} \mathrm{C}$. Aqueous phase, separated by centrifugation and prepurified by dialysis, was incubated in the presence of DNase, RNase, magnesium sulfate, and chloroform. The mixture was again purified by dialysis, once against acetate buffer $(\mathrm{pH} 5)$ and three times against water. After adjusting of $\mathrm{pH}$ to 8 with Tris buffer, the solution was incubated with proteinase $\mathrm{K}$ and dialyzed against water.

2.3. Analysis of Core and O-Antigen Composition. For determining carbohydrate profile of the core and the O-specific region, hydrolysis with $1 \%$ acetic acid $\left(2 \mathrm{~h}, 100^{\circ} \mathrm{C}\right)$ was used to separate polysaccharide fragment of endotoxin from the lipid A which precipitated during centrifugation at $3400 \times \mathrm{g}$ [25]. The supernatant was evaporated in a stream of argon, and the remaining sugar constituents were prereduced with aqueous-methanolic solution of $\mathrm{NaBD}_{4}$ [25]. The oligosaccharide derivative was hydrolyzed with $2 \mathrm{M}$ trifluoroacetic acid (TFA) at $121^{\circ} \mathrm{C}$ for $2 \mathrm{~h}$ [26]. After evaporation, monosaccharides were reduced to alditols with $\mathrm{NaBD}_{4}$ in $1 \mathrm{M}$ ammonia $(10 \mathrm{mg} / \mathrm{mL})$ at $4^{\circ} \mathrm{C}$ for $12 \mathrm{~h}[26,27]$. The excess of reducing agent was removed with glacial acetic acid, and the borates formed were evaporated in a stream of argon. Then, three portions of $10 \%$ acetic acid in methanol 
followed by one portion of methanol alone were added, and the solvent was evaporated in a stream of argon every time. The obtained alditols were $\mathrm{N}$-acetylated by incubation in the presence of acetic anhydride and saturated solution of sodium bicarbonate at room temperature for $30 \mathrm{~min}$ [26]. $\mathrm{O}$-acetylation of the alditols was performed by incubation of the sample with acetic anhydride at $120^{\circ} \mathrm{C}$ for $20 \mathrm{~min}$ in the presence of sodium acetate as a catalyst [28]. The reaction mixture was then evaporated in the presence of toluene, washed with dichloromethane, and reevaporated. The alditol acetates were extracted with hexane/water mixture $(1: 1, \mathrm{v} / \mathrm{v})$ and analyzed by GC/MS technique.

The analyses were performed with the use of a Hewlett Packard 5890 series II gas chromatograph interfaced to a Hewlett Packard 5989A mass spectrometer. The carbohydrate derivatives were separated on a RESTEK RTX5MS fused silica capillary column (5\% diphenyl, 95\% dimethylpolysiloxane, and $60 \mathrm{~m} \times 0.32 \mathrm{~mm}$ i.d.; film thickness: $0.25 \mu \mathrm{m}$ ). The GC oven temperature was programmed from $100^{\circ} \mathrm{C}$ (isothermal for $1 \mathrm{~min}$ ) to $180^{\circ} \mathrm{C}$ at a rate of $20^{\circ} \mathrm{C} / \mathrm{min}$, then to $250^{\circ} \mathrm{C}$ at a rate of $3^{\circ} \mathrm{C} / \mathrm{min}$. The final temperature was held for $12 \mathrm{~min}$. Helium was used as a carrier gas at a flow rate of $1.8 \mathrm{~mL} / \mathrm{min}$, and the GC column outlet was connected directly to the ion source of a mass spectrometer. The GC/MS interface was kept at $280^{\circ} \mathrm{C}$, while the ion source and the quadrupole analyzer were maintained at $200^{\circ} \mathrm{C}$ and $100^{\circ} \mathrm{C}$, respectively.

2.4. GC/MS Identification of Kdo and GlcN in Examined LPS. LPS isolated from $D$. desulfuricans was methanolyzed for $1 \mathrm{~h}$ at $100^{\circ} \mathrm{C}$ with $2 \mathrm{M}$ methanolic hydrochloric acid $(0.5 \mathrm{~mL})$, obtained in the reaction of acetyl chloride with anhydrous methanol. The sample was evaporated under the stream of argon, and methyl glycosides were acetylated at $100^{\circ} \mathrm{C}$ by $30 \mathrm{~min}$ with acetic anhydride $(100 \mu \mathrm{L})$ in the presence of pyridine $(100 \mu \mathrm{L})$. Acetylation reagents were removed under a stream of argon, and sample was washed twice with methanol and applied on GC/MS [29]. Analysis was performed on the same apparatus as in case of carbohydrates, which was equipped with HP-1MS capillary column $(60 \mathrm{~m}-$ length, $0.32 \mathrm{~mm}$-internal diameter, $0.25 \mu \mathrm{m}$-film), at the programmed temperature: $50^{\circ} \mathrm{C}$ initial temperature for $1 \mathrm{~min}$, raised to $160^{\circ} \mathrm{C}$ with $20^{\circ} / \mathrm{min}$ and then raised to $260^{\circ} \mathrm{C}$ with $4^{\circ} / \mathrm{min}$. Separated products were analyzed by Hewlett Packard HP 5989A mass spectrometer. Ionization was performed by $70 \mathrm{eV}$ electron impact (ion source temperature$200^{\circ} \mathrm{C}$, quadrupole $-100^{\circ} \mathrm{C}$ ).

2.5. Determination of Lipid A Fatty Acids and 3-Acyloxyacyl Residues. Ester-, amide-bound total fatty acids, and 3acyloxyacyl residues present in $D$. desulfuricans lipid A were analyzed by a gas chromatography coupled with mass spectrometry (GC/MS) according to the procedures described by Wollenweber and Rietschel [19]. To determine the total fatty acid profile, endotoxin was treated with $\mathrm{HCl}$ followed by methanolic $\mathrm{HCl}$, and the obtained methyl esters were analyzed by GC/MS.

Ester-bound fatty acids were selectively liberated from endotoxin by methanolic $\mathrm{NaOCH}_{3}$ as the corresponding methyl esters and subjected to GC/MS analysis. Treatment of LPS with methanolic $\mathrm{NaOCH}_{3}$ yielded de-O-acetylated LPS containing amide-bound fatty acids that were analyzed using the procedure for total fatty acid determination [19].

To determine 3-acyloxyacyl residues, lipid A was prepared by mild acid hydrolysis of LPS ( $1 \%$ acetic acid; $1 \mathrm{~h} ; 100^{\circ} \mathrm{C}$ ), and amide-bound 3-acyloxyacyl residues were liberated from it in the form of their methyl esters after conversion to acid-labile imidate by methyl iodide in the presence of silver salts. Ester-bound 3-acyloxyacyl residues were liberated as well, due to the presence of trace amount of water. Therefore, to distinguish between ester- and amidebound compounds, the procedure was conducted once in the presence and once in the absence of methyl iodide.

The analyses of fatty acid and 3-acyloxyacyl residues were carried out on Hewlett-Packard gas chromatograph (HP5890 II) coupled with mass spectrometer (HP5989A). Capillary column HP5-MS ( $60 \mathrm{~m}$; i.d. $0.32 \mathrm{~mm}$; film $0.25 \mu \mathrm{m}$; Agilent Technologies) was used. Samples of total, ester- and amidebound fatty acid methyl esters were injected on a column at $60^{\circ} \mathrm{C}$ in the splitless mode. The oven temperature was programmed from $60^{\circ} \mathrm{C}$ to $100^{\circ} \mathrm{C}$ at $10^{\circ} \mathrm{C} / \mathrm{min}$, then at $5^{\circ} \mathrm{C} / \mathrm{min}$ up to $260^{\circ} \mathrm{C}$ which was maintained for $13 \mathrm{~min}$. The samples of 3-acyloxyacyl derivatives were injected on a column at $50^{\circ} \mathrm{C}$ in the splitless mode. The oven temperature was programmed from $50^{\circ} \mathrm{C}$ to $160^{\circ} \mathrm{C}$ at $20^{\circ} \mathrm{C} / \mathrm{min}$, then at $3^{\circ} \mathrm{C} / \mathrm{min}$ up to $290^{\circ} \mathrm{C}$ which was maintained for $25 \mathrm{~min}$.

2.6. UV-Vis Determination of 2-Keto-3-deoxyoctonic Acid (Kdo), Glucosamine $(G l c N)$, and Phosphate Groups. The presence of Kdo in endotoxin was verified spectrophotometrically by the thiobarbituric acid method [30]. LPS was hydrolyzed with sulphuric (VI) acid at $100^{\circ} \mathrm{C}$ for $30 \mathrm{~min}$ to liberate Kdo. Then, Kdo was subjected to react successively with periodic acid, sodium arsenite (III), and thiobarbituric acid to form a chromophore with absorbance maximum at $550 \mathrm{~nm}$.

Hexosamine was analyzed by spectrophotometry according to the Elson-Morgan method [31]. LPS was incubated with $2 \mathrm{M}$ TFA for $1 \mathrm{~h}$ at $120^{\circ} \mathrm{C}$. Next, the sample was evaporated under the stream of nitrogen, water, and basic acetylacetone (obtained by mixing of acetylacetone with sodium carbonate) were added, and mixture was incubated for $15 \mathrm{~min}$ at $100^{\circ} \mathrm{C}$. Afterwards, $p$-aminobenzaldehyde (ADAB) solution $(4 \mathrm{~g}$ ADAB dissolved in $300 \mathrm{~mL}$ of $\mathrm{HCl}$ mixed with ethanol; $1: 5 ; \mathrm{v}: \mathrm{v}$ ) was added, and incubation was continued for $30 \mathrm{~min}$ at $75^{\circ} \mathrm{C}$. After cooling, the absorbance was measured at $512 \mathrm{~nm}$ using Hewlett-Packard type $8452 \mathrm{~A}$ spectrophotometer.

Phosphate content in LPS was evaluated by the Bartlett's method [32]. LPS was dissolved in the deionized water, 5M sulfuric (VI) acid was added, and sample was incubated for $3 \mathrm{~h}$ at $150-160^{\circ} \mathrm{C} .30 \% \mathrm{H}_{2} \mathrm{O}_{2}$ was then added, and incubation was continued at $150-160^{\circ} \mathrm{C}$ for $1.5 \mathrm{~h}$. After cooling, $0.22 \%$ ammonium molybdate and Fiske-SubbaRow reagent were added, and the reaction mixture was heated on the water bath. The absorbance was measured at $820 \mathrm{~nm}$. 


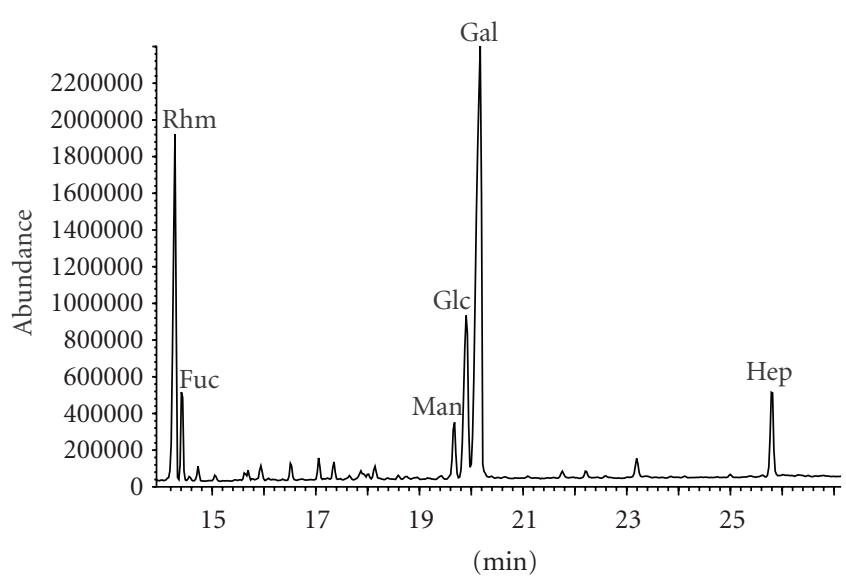

Figure 2: Chromatogram of alditol acetates derived from the core and $\mathrm{O}$-antigen of $D$. desulfuricans endotoxin.

\section{Results}

3.1. Carbohydrates of Core and O-Antigen of Endotoxin. The interpretation of chromatogram (Figure 2) and mass spectra of alditol acetates revealed rhamnose, fucose, mannose, glucose, galactose, and heptose as the components of polysaccharide chain of $D$. desulfuricans LPS. Galactose and rhamnose were predominant carbohydrates in LPS structure, accounting for $45.3 \%$ and $23.3 \%$ of all identified sugars, respectively (Table 1). The percentage of fucose was five times lower than rhamnose. The content of mannose was also low (4.2\%), whereas glucose amounted to $16.4 \%$ in carbohydrate profile. Moreover, the derivatization of carbohydrates of the investigated endotoxin to acetylated methyl glycosides showed that Kdo and glucosamine were also present in its structure (Figure 3). The quantity of Kdo, Glc and phosphate groups per $1 \mathrm{mg}$ of investigated LPS is presented in Table 2.

3.2. Total Fatty Acids. The GC/MS analysis showed fatty acids of the C12-C18 chain length in D. desulfuricans endotoxin (Table 3 and Figure 4(a)). The predominant fatty acid was 3-hydroxytetradecanoic acid (3-OH 14:0). Its derivatization produced not only its methyl ester but also methyl esters of 3-metoxytetradecanoic acid (3-OMe 14:0) and tetradecenoic acid (14:1). Furthermore, dodecanoic (12:0), tetradecanoic (14:0) and hexadecanoic acid (16:0) methyl esters were found in significant amounts among analyzed compounds. The other fatty acid derivatives were detected in smaller amounts.

3.3. Ester- and Amide-Bound Fatty Acids. The fatty acid analysis revealed that $12: 0 ; 14: 0 ; 3-\mathrm{OH} 14: 0$ and $16: 0$ were esterbound in lipid A, as peaks of their derivatives predominated on the obtained chromatograms (Figure 4(b)). The peak of 3-OMe 14:0 acid methyl ester was derived from 3-OH 14:0 substituted at its hydroxy group by other fatty acid, following its reaction with methanolic $\mathrm{NaOCH}_{3}$. Therefore, it can be suggested that this fatty acid was a component of ester-bound 3-acyloxyacyl residue. Other low-intensity peaks probably originated, as it was also observed in the total fatty acid analysis, from contamination of LPS extracts by membrane lipids. The GC/MS analysis also showed that the only amidebound fatty acid in the investigated endotoxin was 3-OH 14:0 (Figure 4(c)). The peaks of 14:1 and 3-OMe 14:0 derivatives, seen on chromatograms, are artifacts formed from $3-\mathrm{OH}$ 14:0 fatty acid during derivatization procedure.

3.4. 3-Acyloxyacyl Residues of Lipid A. 3-(dodecanoyloxy) tetradecanoic, 3-(tetradecanoyloxy)tetradecanoic, and 3(hexadecanoyloxy)tetradecanoic acids were identified in lipid A of D. desulfuricans DV/A strain (Figure 5(a)). The derivatization procedure conducted in the absence of $\mathrm{CH}_{3} \mathrm{I}$ indicated that 3-(tetradecanoyloxy)tetradecanoic acid was ester-linked to glucosamine core of lipid A, whereas the two other 3-acyloxyacyls were amide-bound to it (Figure 5(b)). Due to the lack of 3-acyloxyacyl methyl ester spectra in the mass spectra database (Wiley 7), the identification of these compounds was performed by the comparison with theoretical fragmentation and with spectra found in other papers [33-35]. The obtained mass spectra of 3-acyloxyacyl methyl esters are shown in Figure 5. As a characteristic for each of these residues, molecular ions $\left(\mathrm{M}^{+}\right)$at $m / z=440,468$, and 496 were used as a major criterion of their identification. Ions at $m / z=241$ and 257, observed on every spectrum, indicate 3-hydroxytetradecanoic acid, whereas substituents of 3-OH 14:0 were identified by the presence of ions at $m / z=183\left(\mathrm{CH}_{3}\left(\mathrm{CH}_{2}\right)_{10} \mathrm{CO}\right), 211\left(\mathrm{CH}_{3}\left(\mathrm{CH}_{2}\right)_{12} \mathrm{CO}\right)$, and $239\left(\mathrm{CH}_{3}\left(\mathrm{CH}_{2}\right)_{14} \mathrm{CO}\right)$ on the respective mass spectra (Figures 5(c)-5(e)).

\section{Discussion}

Endotoxin is an immunogen stimulating the immune system cells to liberate the inflammatory mediators, which can cause pathophysiological effects such as septic shock, leukopenia, leukocytosis, activation of complement, hyperglycemia, lowering of blood pressure, and Shwartzman reaction.

Endotoxin of $D$. desulfuricans DV/A strain had no stimulatory effect on epithelial colon cells Caco-2 [36]. These cells did not release IL- 8 after stimulation with DV/A endotoxin; however following incubation with LPS and sodium butyrate, the increase of IL- 8 synthesis was observed $[37,38]$. Furthermore, the treatment of Caco-2 cells for $1 \mathrm{~h}$ with increasing concentrations of this LPS (10, 50, and $100 \mu \mathrm{g} / \mathrm{mL}$ ) resulted in the decrease of IL-6 and IL-6 receptor genes expression, whereas elongation of treatment with $50 \mu \mathrm{g} / \mathrm{mL}$ of LPS to $6 \mathrm{~h}$ increased transcriptional activity of both genes [39]. D. desulfuricans endotoxin enhanced the secretion of IL-6 and IL-8, and induced the expression of adhesion molecules - selectin E and VCAM-1 (vascular adhesion molecule-1) in vascular endothelial cells, what indicates that it influences the expression of genes-encoding proteins involved in inflammatory processes [37]. LPS of the investigated bacteria in the concentration of $30 \mu \mathrm{g} / \mathrm{mL}$ decreased metabolic activity of V-79 fibroblasts, inhibited their growth and caused the apoptosis of these cells, indicating its influence on cell proliferation [40]. Dzierżewicz et al. [41] found that endotoxin of D. desulfuricans DV/A strain in concentration of $100 \mu \mathrm{g} / \mathrm{mL}$ inhibited the growth 


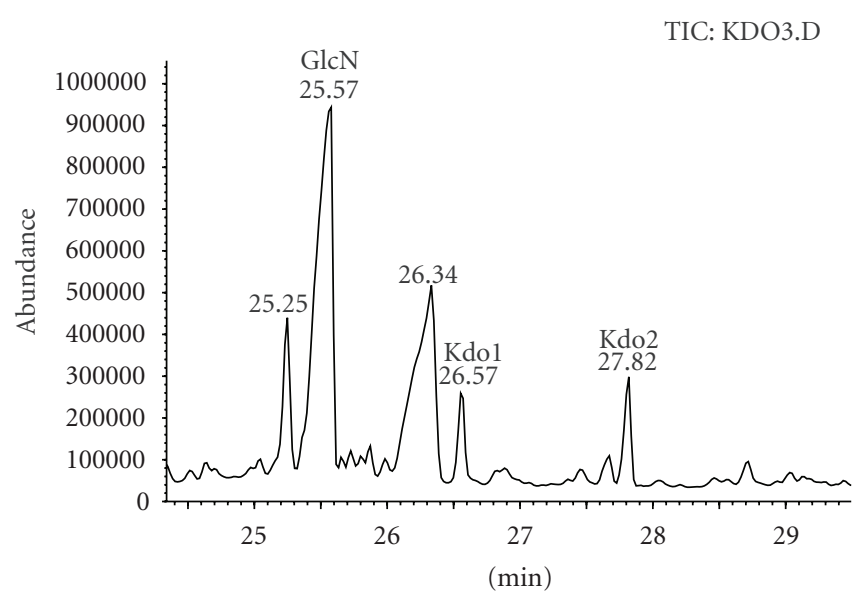

(a)

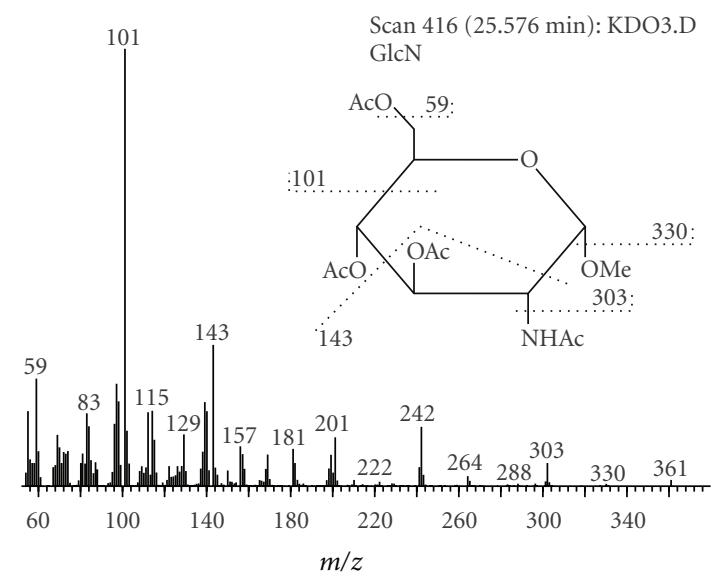

(b)

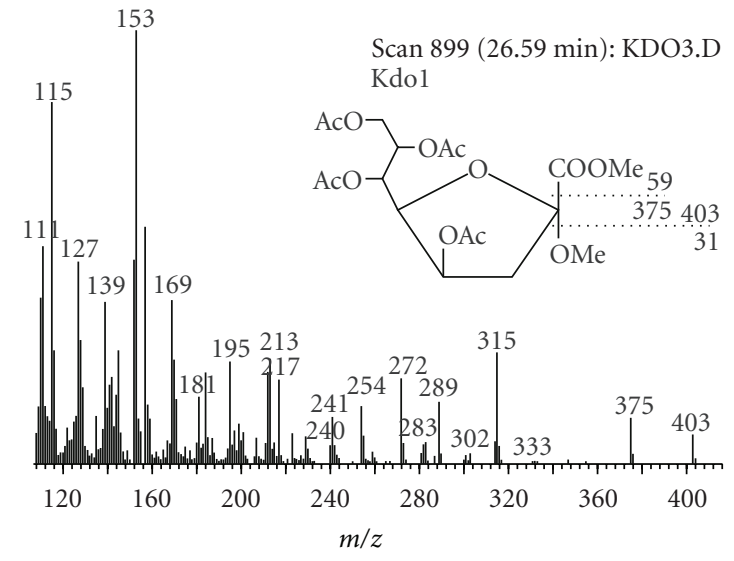

(c)

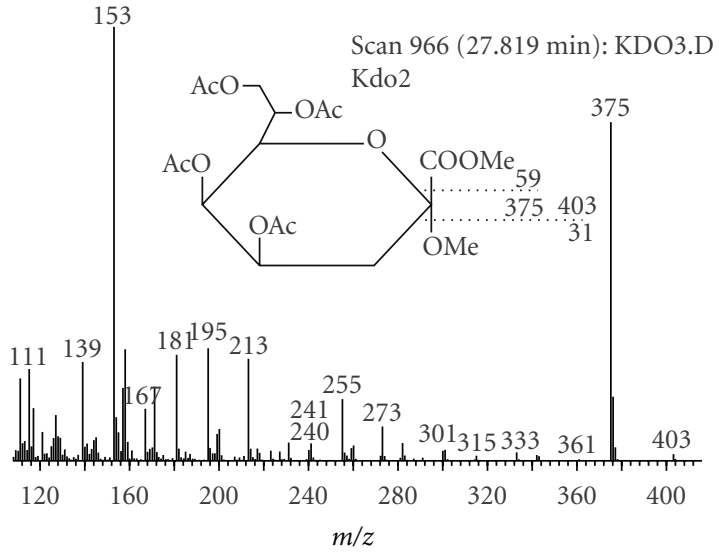

(d)

FIGURE 3: Chromatogram and mass spectra of glucosamine and Kdo methyl glycoside originated from LPS of D. desulfuricans.

TABLE 1: Quantities of carbohydrates in polysaccharide chain of D. desulfuricans endotoxin.

\begin{tabular}{lcccccc}
\hline & Rhamnose & Fucose & Mannose & Glucose & Galactose & Heptose \\
\hline$\% A U P \pm S D$ & $23.3 \pm 2.1$ & $5.0 \pm 0.5$ & $4.2 \pm 0.5$ & $16.4 \pm 2.5$ & $45.3 \pm 5.4$ & $5.8 \pm 0.3$ \\
\hline
\end{tabular}

\%AUP: percentage of area under the peak of carbohydrate in the carbohydrate profile of core and O-antigen.

SD: standard deviation.

TABLE 2: The quantity of Kdo and GlcN i phosphates $\left(\mathrm{PO}_{4}\right)$ in LPS of $D$. desulfuricans intestinal strain (DV/A).

\begin{tabular}{lcc}
\hline \multicolumn{3}{c}{$\mathrm{m}(\mu \mathrm{g} / \mathrm{mg}$ LPS $)$} \\
Kdo & GlcN & $\mathrm{PO}_{4}$ \\
\hline $25.8 \pm 0.5$ & $23.1 \pm 2.7$ & $12.6 \pm 0.4$ \\
\hline
\end{tabular}

of human gingival fibroblasts HGF-1, whereas at its lower concentrations this effect was not observed. Moreover, $D$. desulfuricans endotoxin enhanced the secretion of IL- 6 and IL- 8 by HGF- 1 cells and showed the ability to induce TNF $\alpha$ synthesis by mononuclear blood cells [21].

The above-mentioned biological activity of $D$. desulfuricans endotoxin is determined by its chemical structure. The structure of lipid A, the center of LPS toxicity, influences the immunomodulatory properties of endotoxin. Wolny et al. [42] proved that two molecules of glucosamine, probably linked by the $\beta(1 \rightarrow 6)$ glycosidic bond, were the constituents of carbohydrate core of lipid A. The structurally similar lipid A core is synthesized by Escherichia coli [43], Moraxella catarrhalis [44], Proteus mirabilis [45], Neisseria meningitidis [46], Rhodobacter sphaeroides [47], and many other bacteria. In the present study, 3-(dodecanoyloxy)tetradecanoic and 3-(tetradecanoyloxy)tetradecanoic residues were found to be amide-bound and 3-(hexadecanoyloxy)tetradecanoic residue was ester-bound to the disaccharide core of $D$. desulfuricans DV/A lipid A, which means that dodecanoic, tetradecanoic, hexadecanoic, and 3-hydroxytetradecanoic acids are components of the investigated LPS. This observation is congruent with findings of Wolny et al. [42] concerning the fatty acid profile of several other $D$. 


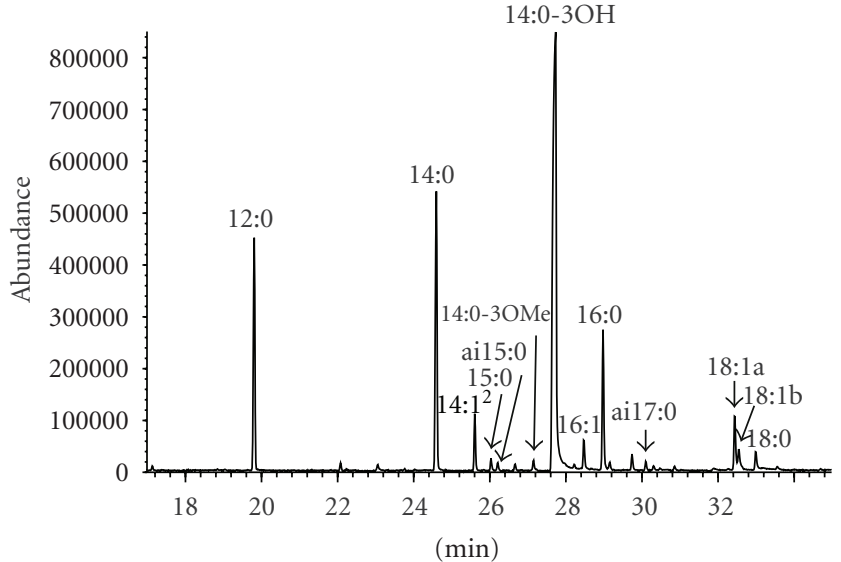

(a)

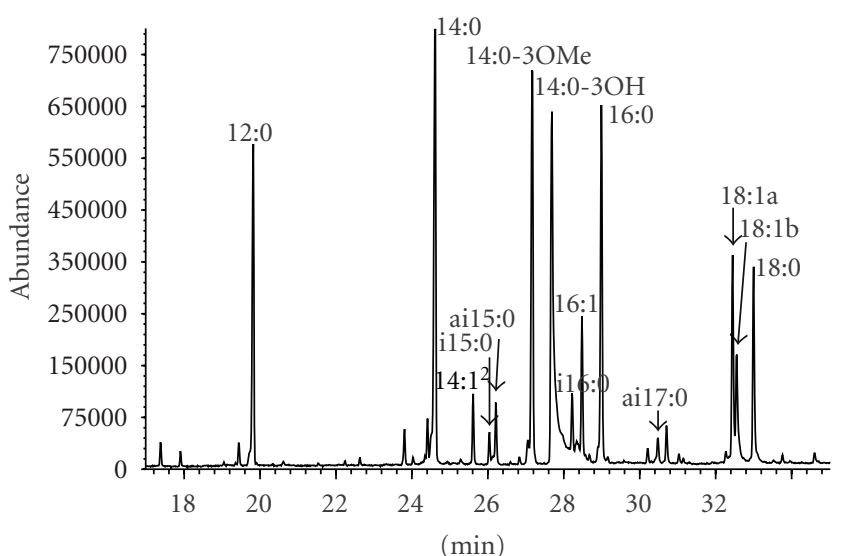

(b)

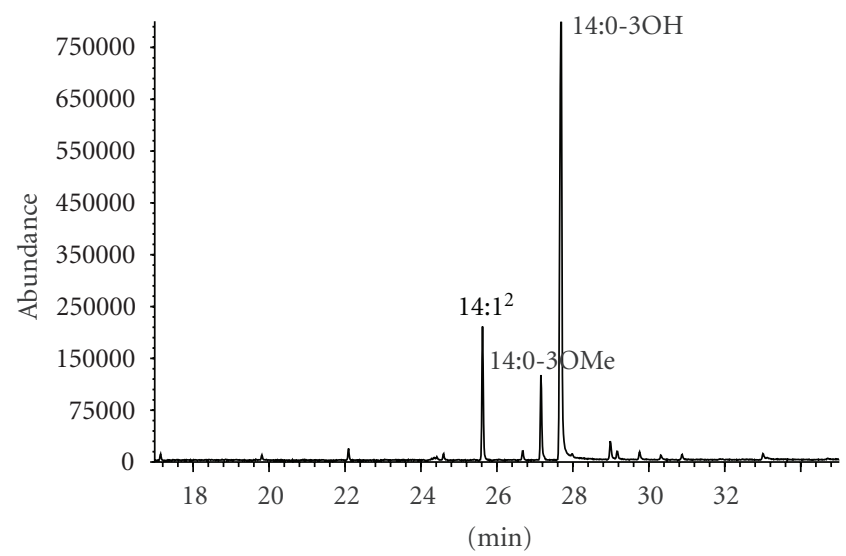

(c)

FIgure 4: Chromatogram of methyl derivatives of fatty acids being the constituents of $D$. desulfuricans LPS (a) total fatty acids, (b) esterbound fatty acids, (c) amide-bound fatty acids).

TABLe 3: Fatty acid profile of $D$. desulfuricans endotoxin.

\begin{tabular}{lc}
\hline & $\% A U P \pm S D$ \\
\hline $12: 0$ & $12.1 \pm 0.09$ \\
$14: 0$ & $16.1 \pm 0.1$ \\
$15: 0$ & $0.6 \pm 0.06$ \\
ai15:0 & $0.4 \pm 0.03$ \\
$3 \mathrm{OH} 14: 0$ & $53.2 \pm 0.16$ \\
$16: 1$ & $1.7 \pm 0.11$ \\
$16: 0$ & $7.1 \pm 0.14$ \\
ai17:0 & $0.6 \pm 0.25$ \\
$18: 1 \mathrm{a}$ & $3.1 \pm 0.15$ \\
$18: 1 \mathrm{~b}$ & $1.7 \pm 0.08$ \\
$18: 0$ & $1.1 \pm 0.09$ \\
\hline
\end{tabular}

\%AUP: percentage of area under the peak of fatty acid in the fatty acid profile of $D$. desulfuricans endotoxin.

SD: standard deviation.

desulfuricans strains. These fatty acids could also be found in lipid A of Escherichia coli [43], Proteus mirabilis [45], Haemophilus influenzae [48], Neisseria meningitidis [46], Salmonella typhimurium [49], and so forth.
Among derivatives of $D$. desulfuricans LPS fatty acids, besides just mentioned 3-OH 14:0; 12:0; 14:0 and 16:0, small amounts of branched (i15:0, ai15:0, i16:0 and ai17:0), unsaturated (16:1 and 18:1) and 18:0 fatty acids were also identified. Probably, these fatty acids are not components of investigated strain lipid A and their presence in analyzed samples is a result of their strong association with lipopolysaccharides. These fatty acids may be constituents of cellular membrane lipids because they were identified as a cellular fatty acids in D. desulfuricans [50]. Edlund et al. [51] identified different fatty acids with chain length of 14 to 19 carbon atoms, both straight and branched, saturated, and unsaturated with diversified location of double bonds in lipopolysaccharide of $D$. desulfuricans. While, Gaylarde and Beech [52], investigating D. desulfuricans LPS chemical composition, identified atypical for such structures fatty acids8 -octadecenoic and tetracosanoic acid. They demonstrated also 9-octadecenoic, 10-octadecenoic, heptadecenoics, and eicosenoic acids, but no hydroxy fatty acids in lipid A of these bacteria.

The high biological activity of lipid A is caused by the presence of six, asymmetrically located fatty acids and also by the presence of additional substituents, for example, 


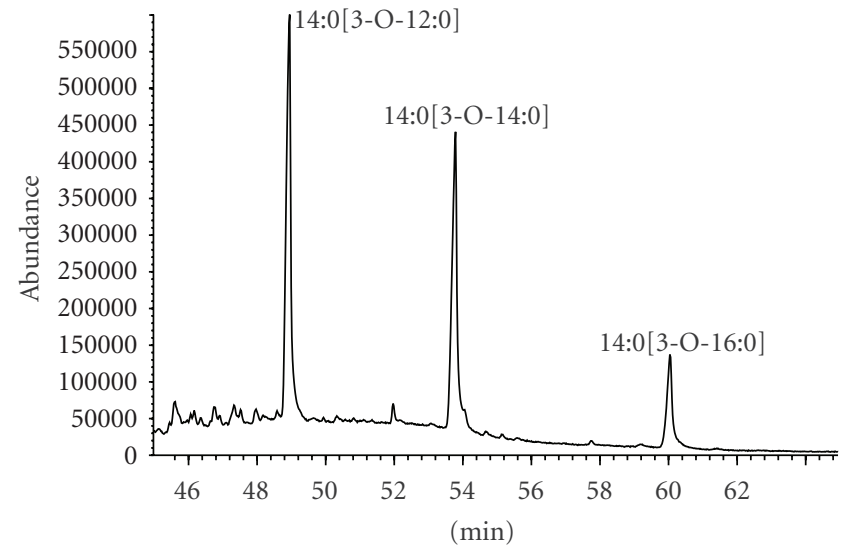

(a)

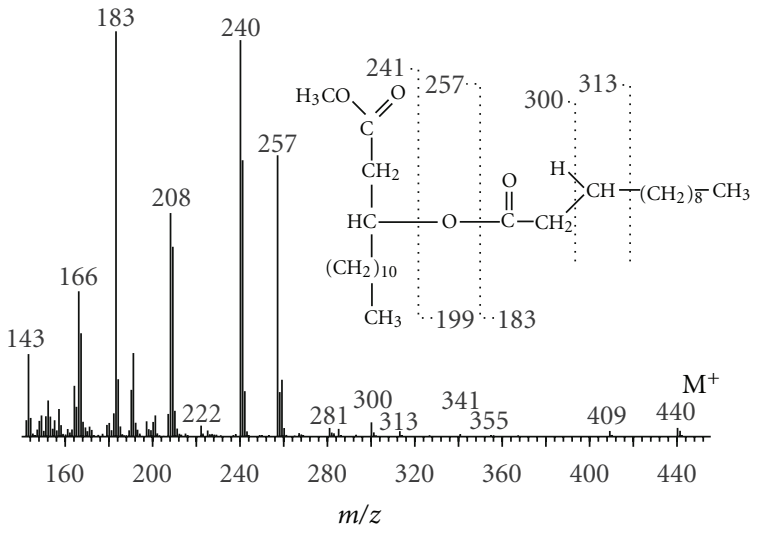

(c)

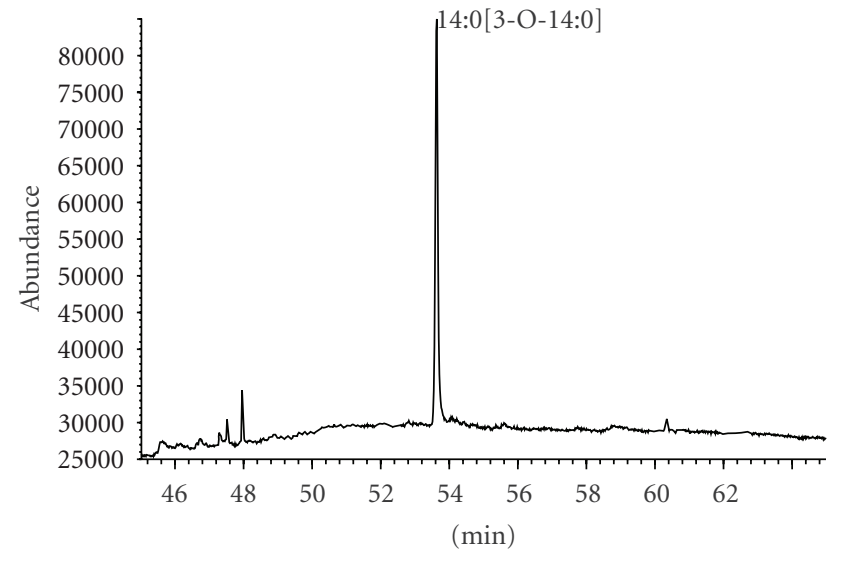

(b)

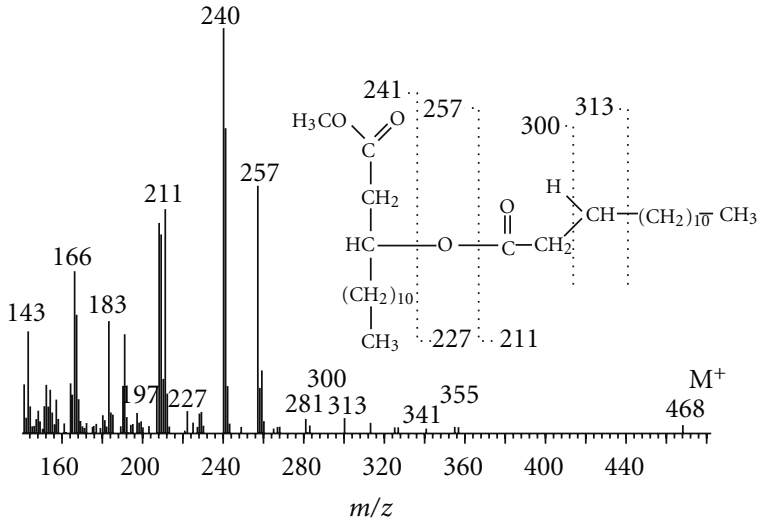

(d)

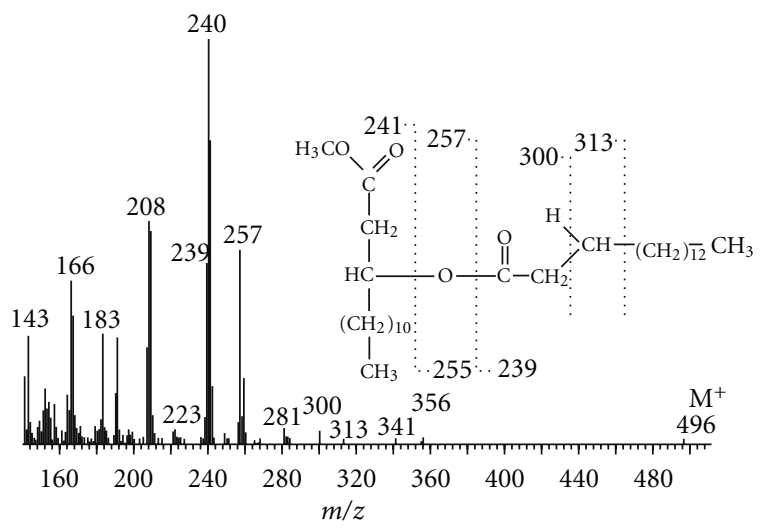

(e)

FIgURE 5: Chromatograms and mass spectra of 3-acyloxyacyl ligands of carbohydrate core of D. desulfuricans lipid A (chromatogram of derivatives obtained in the presence (a) and in absence (b) of methyl iodide; mass spectrum of 3-(dodecanoyloxy)tetradecanoic (c), 3(tetradecanoyloxy)tetradecanoic (d), and 3-(hexadecanoyloxy)tetradecanoic (e) methyl esters).

phosphate groups. Rietschel et al. [53] claim that the fewer phosphate groups occur in lipid A the less it is active. The lack of one of the phosphate substituents results in 100 times lower biological activity of LPS. Lipid A of D. desulfuricans is phosphorylated the thing that influences its activity.

The chemical structure of many microorganisms, for example, Proteus penneri 71 [54], Proteus penneri 63 [55], Pseudomonas syringae pv. garcae ICMP 8047 [56], Yersinia enterocolitica serotype O:28 [57], and Vibrio cholerae H11 [58] has been elucidated so far; however, there is little know about the structure of carbohydrate part of $D$. desulfuricans LPS. Gaylarde and Beech [52] only attempted to determine the carbohydrate profile of these bacteria endotoxin. They identified rhamnose, glucose, galactose, mannose, and ribose. These findings are considerably similar to the results presented in this paper because all these sugars, except ribose, 
were detected. The presence of ribose in the investigated LPS is questionable, since Gaylarde and Beech [52] themselves admitted that this carbohydrate originated from nucleic acids being the impurities of the sample.

Rhamnose was found in the analyzed endotoxin. This 6-deoxyhexose commonly occurs in lipopolysaccharides. It was detected in LPS of Salmonella arizonae O62 [59], S. enteritidis [60], Shigella dysenteriae [61], Pseudomonas syringae pv. ribicola NCPPB 1010 [62], and pv. garcae ICMP 8047 [56]. There was also other methylopentosefucose and three hexoses-mannose, glucose, and galactosein the polysaccharide chain of the investigated strain of $D$. desulfuricans. Hexoses may be constituents of not only Oantigen but also the outer part of the oligosaccharide core, whereas, heptose is component of the inner part of the core. In endotoxin of many microorganisms, the heptose part of oligosaccharide core is linked with $\mathrm{Kdo}$, which in turn is linked with lipid A. Gaylarde and Beech [52] suggested the lack of Kdo in D. desulfuricans LPS. The GC/MS analysis of alditol acetates obtained after derivatization of DV/A strain seemed to prove the hypothesis of Gaylarde and Beech because the derivative of Kdo was not identified. However, since Kdo is a labile compound, decomposing in the conditions of derivatization to the alditol acetates $[63,64]$, the presence of this sugar in D. desulfuricans LPS was verified by its analysis in the form of acetylated glycosides. This allowed confirming that this eight-carbon ketose with carboxylic group is a component of investigated LPS. The UV-Vis determination of this sugar allowed establishing that the quantity of Kdo per $1 \mathrm{mg}$ of LPS was $25.8 \mu \mathrm{g}$. According to Lee and Tsai [65], the thiobarbituric acid method cannot be used when Kdo is substituted at position 4 or 5 , which prevents its oxidation by periodic acid. The investigation of Carof et al. [66], concerning the structure of Bordetella pertussis endotoxin, also proved that Kdo with phosphate group or phosphoethanolamine at position 4 cannot be determined by thiobarbituric acid method. Thus, the results showed in this paper suggest that Kdo, present in D. desulfuricans endotoxin, has no substituents at position 4 or 5 . It should be pointed out that 3,6dideoxyhexose-abequose and colitose-can also react with thiobarbituric acid [67]; however, these carbohydrates are rare in bacterial endotoxins except Enterobacteriaceae, and the GC/MS analysis did not show their presence.

\section{References}

[1] M. Fournier, Y. Zhang, J. D. Wildschut et al., "Function of oxygen resistance proteins in the anaerobic, sulfate-reducing bacterium Desulfovibrio vulgaris Hildenborough," Journal of Bacteriology, vol. 185, no. 1, pp. 71-79, 2003.

[2] L. Schoenborn, H. Abdollahi, W. Tee, M. Dyall-Smith, and P. H. Janssen, "A member of the delta subgroup of proteobacteria from a pyogenic liver abscess is a typical sulfate reducer of the genus Desulfovibrio," Journal of Clinical Microbiology, vol. 39, no. 2, pp. 787-790, 2001.

[3] P. Sigalevich, M. V. Baev, A. Teske, and Y. Cohen, "Sulfate reduction and possible aerobic metabolism of the sulfatereducing bacterium Desulfovibrio oxyclinae in a chemostat coculture with Marinobacter sp. strain MB under exposure to increasing oxygen concentrations," Applied and Environmental Microbiology, vol. 66, no. 11, pp. 5013-5018, 2000.

[4] H. Abdollahi and J. W. T. Wimpenny, "Effects of oxygen on the growth of Desulfovibrio desulfuricans," Journal of General Microbiology, vol. 136, no. 6, pp. 1025-1030, 1990.

[5] R. K. Porschen and P. Chan, "Anaerobic vibrio like organisms cultured from blood: Desulfovibrio desulfuricans and Succinivibrio species," Journal of Clinical Microbiology, vol. 5, no. 4, pp. 444-447, 1977.

[6] Y. A. Warren, D. M. Citron, C. V. Merriam, and E. J. C. Goldstein, "Biochemical differentiation and comparison of Desulfovibrio species and other phenotypically similar genera," Journal of Clinical Microbiology, vol. 43, no. 8, pp. 4041-4045, 2005.

[7] W. Tee, M. Dyall-Smith, W. Woods, and D. Eisen, "Probable new species of Desulfovibiro isolated from a pyogenic liver abscess," Journal of Clinical Microbiology, vol. 34, no. 7, pp. 1760-1764, 1996.

[8] A. Lozniewski, P. Maurer, H. Schuhmacher, J. P. Carlier, and F. Mory, "First isolation of Desulfovibrio species as part of a polymicrobial infection from a brain abscess," European Journal of Clinical Microbiology and Infectious Diseases, vol. 18, no. 8, pp. 602-603, 1999.

[9] E. J. Baron, R. Bennion, J. Thompson et al., "A microbiological comparison between acute and complicated appendicitis," Clinical Infectious Diseases, vol. 14, no. 1, pp. 227-231, 1992.

[10] G. R. Gibson, J. H. Cummings, and G. T. Macfarlane, "Growth and activities of sulphate-reducing bacteria in gut contents of healthy subjects and patients with ulcerative colitis," FEMS Microbiology Ecology, vol. 86, no. 2, pp. 103-112, 1991.

[11] T. H. J. Florin, G. R. Gibson, G. Neale, and J. H. Cummings, "A role for sulfate reducing bacteria in ulcerative colitis?" Gastroenterology, vol. 98, p. A170, 1990.

[12] R. Boopathy, M. Robichaux, D. LaFont, and M. Howell, "Activity of sulfate-reducing bacteria in human periodontal pocket," Canadian Journal of Microbiology, vol. 48, no. 12, pp. 10991103, 2002.

[13] P. S. Langendijk, E. M. Kulik, H. Sandmeier, J. Meyer, and J. S. van der Hoeven, "Isolation of Desulfomicrobium orale sp. nov. and Desulfovibrio strain NY682, oral sulfate-reducing bacteria involved in human periodontal disease," International Journal of Systematic and Evolutionary Microbiology, vol. 51, no. 3, pp. 1035-1044, 2001.

[14] L. M. Beynon, J. C. Richards, and M. B. Perry, "The structure of the lipopolysaccharide $\mathrm{O}$ antigen from Yersinia ruckeri serotype 01," Carbohydrate Research, vol. 256, no. 2, pp. 303317, 1994.

[15] E. V. Vinogradov, Z. Sidorczyk, A. Swierzko et al., "The structure of the O-specific polysaccharide chain of Proteus penneri strain 16 lipopolysaccharide," European Journal of Biochemistry, vol. 197, no. 1, pp. 93-103, 1991.

[16] Z. Sidorczyk, A. Swierzko, K. Zych et al., "Structure of the Ospecific polysaccharide chain and serological characterization of the Proteus penneri 62 lipopolysaccharide compared with the lipopolysaccharides of the P. penneri strains," Archivum Immunologiae et Therapiae Experimentalis (Warsz), vol. 44, no. 2-3, pp. 179-185, 1996.

[17] A. Gamian, C. Jones, T. Lipiński, A. Korzeniowska-Kowal, and N. Ravenscroft, "Structure of the sialic acid-containing Ospecific polysaccharide from Salmonella enterica serovar Toucra O48 lipopolysaccharide," European Journal of Biochemistry, vol. 267, no. 11, pp. 3160-3166, 2000. 
[18] A. Gamian and L. Kenne, "Analysis of 7-substituted sialic acid in some enterobacterial lipopolysaccharides," Journal of Bacteriology, vol. 175, no. 5, pp. 1508-1513, 1993.

[19] H. W. Wollenweber and E. T. Rietschel, "Analysis of lipopolysaccharide (lipid A) fatty acids," Journal of Microbiological Methods, vol. 11, no. 3-4, pp. 195-211, 1990.

[20] S. G. Wilkinson and D. P. Taylor, "Occurrence of 2,3-diamino2,3-dideoxy-D-glucose in lipid A from lipopolysaccharide of Pseudomonas diminuta," Journal of General Microbiology, vol. 109, no. 2, pp. 367-370, 1978.

[21] L. Wȩglarz, B. Parfiniewicz, A. Mertas et al., "Effect of endotoxins isolated from Desulfovibrio desulfuricans soil and intestinal strain on the secretion of TNF- $\alpha$ by human mononuclear cells," Polish Journal of Environmental Studies, vol. 15, no. 4, pp. 615-622, 2006.

[22] J. R. Postgate, The Sulphate Reducing Bacteria, Cambridge University Press, London, UK, 2nd edition, 1984.

[23] O. Westphal, O. Luderitz, and F. Bister, "Uber die exraction von bacterien mit phenol-wasser," Zeitschrift für Naturforschung, vol. 78, pp. 148-155, 1952.

[24] A. Shnyra, M. Lucchi, and D. C. Morrison, "Preparation of endotoxin from pathogenic Gram-negative bacteria," in Septic Shock, T. J. Evans, Ed., vol. 36 of Methods in Molecular Medicine, Humana Press, Totowa, NJ, USA, 2000.

[25] U. R. Bhat, L. S. Forsberg, and R. W. Carlson, "Structure of lipid A component of Rhizobium leguminosarum bv. phas-eoli lipopolysaccharide. Unique nonphosphorylated lipid a containing 2-amino-2- deoxygluconate, galacturonate, and glucosamine," Journal of Biological Chemistry, vol. 269, no. 20, pp. 14402-14410, 1994.

[26] R. K. Merkle and I. Poppe, "Carbohydrate composition analysis of glycoconjugates by gas-liquid chromatography/mass spectrometry," Methods in Enzymology, vol. 230, pp. 1-15, 1994.

[27] W. S. York, A. G. Darvill, M. MacNeil, T. T. Stevenson, and P. Albersheim, "Isolation and characterization of plant cell walls and cell wall components," Methods in Enzymology, vol. 118, pp. 3-41, 1985.

[28] D. E. Heinrichs, M. A. Monteiro, M. B. Perry, and C. Whitfield, "The assembly system for the lipopolysaccharide R2 core-type of Escherichia coli is a hybrid of those found in Escherichia coli K-12 and Salmonella enterica. Structure and function of the R2 WaaK and WaaL homologs," Journal of Biological Chemistry, vol. 273, no. 15, pp. 8849-8859, 1998.

[29] J. Rybka and A. Gamian, "Determination of endotoxin by the measurement of the acetylated methyl glycoside derivative of Kdo with gas-liquid chromatography-mass spectrometry," Journal of Microbiological Methods, vol. 64, no. 2, pp. 171-184, 2006.

[30] Y. D. Karkhanis, J. Y. Zeltner, J. J. Jackson, and D. J. Carlo, “A new and improved microassay to determine 2-keto-3-deoxyoctonate in lipopolysaccharide of gram-negative bacteria," Analytical Biochemistry, vol. 85, no. 2, pp. 595-601, 1978.

[31] Z. Dische, "Color reactions of carbohydrates," Methods in Carbohydrate Chemistry, vol. 1, pp. 477-514, 1962.

[32] G. R. Bartlett, "Phosphorus assay in column chromatography," The Journal of Biological Chemistry, vol. 234, no. 3, pp. 466468, 1959.

[33] H. W. Wollenweber, K. W. Broady, O. Lüderitz, and E. T. Rietschel, "The chemical structure of lipid A. Demonstration of amide-linked 3-acyloxyacyl residues in Salmonella minnesota Re lipopolysaccharide," European Journal of Biochemistry, vol. 124, no. 1, pp. 191-198, 1982.
[34] H. W. Wollenweber, S. Schlecht, O. Luderitz, and E. T. Rietschel, "Fatty acid in lipopolysaccharides of Salmonella species grown at low temperature. Identification and position," European Journal of Biochemistry, vol. 130, no. 1, pp. 167-171, 1983.

[35] H. W. Wollenweber, U. Seydel, B. Lindner, O. Luderitz, and E. T. Rietschel, "Nature and location of amide-bound (R)-3acyloxyacyl groups in lipid A of lipopolysaccharides from various gram-negative bacteria," European Journal of Biochemistry, vol. 145, no. 2, pp. 265-272, 1984.

[36] B. Parfiniewicz, L. Wȩglarz, M. Jaworska-Kik, and A. Zajdel, "Interleukin-6 (IL-6) secretion by malignant epithelial colorectal cells treated with Desulfovibrio desulfuricans lipopolysaccharides," Farmaceutyczny Przeglad Naukowy, vol. 7, no. 2, pp. 15-20, 2010.

[37] L. Wȩglarz, Z. Dzierżewicz, B. Skop et al., "Desulfovibrio desulfuricans lipopolysaccharides induce endothelial cell IL-6 and IL-8 secretion and E-selectin and VCAM-1 expression," Cellular and Molecular Biology Letters, vol. 8, no. 4, pp. 9911003, 2003.

[38] L. Wȩglarz, J. Wawszczyk, A. Orchel, M. Jaworska-Kik, and Z. Dzierzewicz, "Phytic acid modulates in vitro IL-8 and IL6 release from colonic epithelial cells stimulated with LPS and IL-1 $\beta$," Digestive Diseases and Sciences, vol. 52, no. 1, pp. 93$102,2007$.

[39] K. Cholewa, L. Wȩglarz, B. Parfiniewicz, J. Lodowska, and M. Jaworska-Kik, "The influence of Desulfovibrio desulfuricans endotoxin on IL-6 and IL-6 receptor genes expression in colon cancer Caco-2 cells," Farmaceutyczny Przeglad Naukowy, vol. 7, no. 3, pp. 27-32, 2010.

[40] Z. Dzierżewicz, A. Orchel, A. Komarska-Szostak et al., "Biological activity of endotoxins isolated from Desulfovibrio desulfuricans species," Annals Academy of Medicine, vol. 59, pp. 916, 2005.

[41] Z. Dzierżewicz, J. Szczerba, J. Lodowska et al., "The role of Desulfovibrio desulfuricans lipopolysaccharides in modulation of periodontal inflammation through stimulation of human gingival fibroblasts," Archives of Oral Biology, vol. 55, no. 7, pp. 515-522, 2010.

[42] D. Wolny, J. Lodowska, M. Jaworska-Kik, S. Kurkiewicz, L. Wȩglarz, and Z. Dzierzewicz, "Chemical composition of Desulfovibrio desulfuricans lipid A," Archives of Microbiology, vol. 193, no. 1, pp. 15-21, 2011.

[43] U. Seydel, B. Lindner, H. W. Wollenweber, and E. T. Rietschel, "Structural studies on the lipid A component of enterobacterial lipopolysaccharides by laser desorption mass spectrometry. Location of acyl groups at the lipid A backbone," European Journal of Biochemistry, vol. 145, no. 3, pp. 505-509, 1984.

[44] H. Masoud, M. B. Perry, and J. C. Richards, "Characterization of the lipopolysaccharide of Moraxella catarrhalis. Structural analysis of the lipid A from $M$. catarrhalis serotype A lipopolysaccharide," European Journal of Biochemistry, vol. 220, no. 1, pp. 209-216, 1994.

[45] Z. Sidorczyk, U. Zähringer, and E. T. Rietschel, "Chemical structure of the lipid A component of the lipopolysaccharide from a Proteus mirabilis Re-mutant," European Journal of Biochemistry, vol. 137, no. 1-2, pp. 15-22, 1983.

[46] V. A. Kulshin, U. Zahringer, B. Lindner et al., "Structural characterization of the lipid A component of pathogenic Neisseria meningitidis," Journal of Bacteriology, vol. 174, no. 6, pp. 1793-1800, 1992.

[47] W. Strittmatter, J. Weckesser, P. V. Salimath, and C. Galanos, "Nontoxic lipopolysaccharide from Rhodopseudomonas 
sphae-roides ATCC 17023," Journal of Bacteriology, vol. 155, no. 1 , pp. 153-158, 1983.

[48] I. M. Helander, B. Lindner, H. Brade et al., "Chemical structure of the lipopolysaccharide of Haemophilus influenzae strain I69 Rd-/b+. Description of a novel deep-rough chemotype," European Journal of Biochemistry, vol. 177, no. 3, pp. 483-492, 1988.

[49] N. Qureshi, K. Takayama, and E. Ribi, "Purification and structural determination of nontoxic lipid A obtained from the lipopolysaccharide of Salmonella typhimurium," Journal of Biological Chemistry, vol. 257, no. 19, pp. 11808-11815, 1982.

[50] Z. Dzierżewicz, B. Cwalina, S. Kurkiewicz, E. Chodurek, and T. Wilczok, "Intraspecies variability of cellular fatty acids among soil and intestinal strains of Desulfovibrio desulfuricans," Applied and Environmental Microbiology, vol. 62, no. 9, pp. 3360-3365, 1996.

[51] A. Edlund, P. D. Nichols, R. Roffey, and D. C. White, "Extractable and lipopolysaccharide fatty acid and hydroxy acid profiles from Desulfovibrio species," Journal of Lipid Research, vol. 26, no. 8, pp. 982-988, 1985.

[52] C. C. Gaylarde and I. B. Beech, "Short communication: lipopolysaccharide omposition of Desulfovibrio cell," World Journal of Microbiology and Biotechnology, vol. 12, pp. 113114, 1996.

[53] E. T. Rietschel, T. Kirikae, F. U. Schade et al., "Bacterial endotoxin: molecular relationships of structure to activity and function,” FASEB Journal, vol. 8, no. 2, pp. 217-225, 1994.

[54] K. Zych, N. A. Kocharova, M. Kowalczyk et al., "Structure of the O-specific polysaccharide of Proteus penneri 71 and classification of cross-reactive $P$. penneri strains to a new proposed serogroup $\mathrm{O}_{64}$," European Journal of Biochemistry, vol. 267, no. 3, pp. 808-814, 2000.

[55] A. S. Shashkov, A. N. Kondakova, S. N. Senchenkova et al., "Structure of a 2-aminoethyl phosphate-containing O-specific polysaccharide of Proteus penneri 63 from a new serogroup $\mathrm{O}_{68}$," European Journal of Biochemistry, vol. 267, no. 2, pp. 601-605, 2000.

[56] E. L. Zdorovenko, V. V. Ovod, A. S. Shashkov, N. A. Kocharova, Y. A. Knirel, and K. Krohn, "Structure of the O-Polysaccharide of the Lipopolysaccharide of Pseudomonas syringae pv. garcae ICMP 8047," Biochemistry (Moscow), vol. 64, no. 7, pp. 765773, 1999.

[57] M. B. Perry and L. L. MacLean, "Structural identification of the lipopolysaccharide O-antigen produced by Yersinia enterocolitica serotype $\mathrm{O}: 28$," European Journal of Biochemistry, vol. 267, no. 9, pp. 2567-2572, 2000.

[58] E. V. Vinogradov, O. Holst, J. E. Thomas-Oates, K. W. Broady, and $\mathrm{H}$. Brade, "The structure of the $\mathrm{O}$-antigenic polysaccharide from lipopolysaccharide of Vibrio cholerae strain $\mathrm{H} 11$ (non-O1)," European Journal of Biochemistry, vol. 210, no. 2, pp. 491-498, 1992.

[59] E. V. Vinogradov, Y. A. Knirel, N. K. Kochetkov, S. Schlecht, and $\mathrm{H}$. Mayer, "The structure of the O-specific polysaccharide of Salmonella arizonae $\mathrm{O}_{62}$," Carbohydrate Research, vol. 253, pp. 101-110, 1994.

[60] M. M. Rahman, J. Guard-Petter, and R. W. Carlson, "A virulent isolate of Salmonella enteritidis produces a Salmonella typhilike lipopolysaccharide," Journal of Bacteriology, vol. 179, no. 7, pp. 2126-2131, 1997.

[61] H. N. Brahmbhatt, A. A. Lindberg, and K. N. Timmis, "Shigella lipopolysaccharide: structure, genetics, and vaccine development," Current Topics in Microbiology and Immunology, vol. 180, pp. 45-64, 1992.
[62] V. V. Ovod, E. L. Zdorovenko, A. S. Shashkov, N. A. Kocharova, and Y. A. Knirel, "Structure of the O polysaccharide and serological classification of Pseudomonas syringae pv. ribicola NCPPB 1010," European Journal of Biochemistry, vol. 267, no. 8, pp. 2372-2379, 2000.

[63] A. Tacken, H. Brade, F. M. Unger, and D. Charon, "G.L.C.M.S. of partially methylated and acetylated derivatives of 3deoxyoctitols," Carbohydrate Research, vol. 149, no. 2, pp. 263277, 1986.

[64] A. Tacken, E. T. Rietschel, and H. Brade, "Methylation analysis of the heptose/3-deoxy-d-manno-2-octulosonic acid region (inner core) of the lipopolysaccharide from Salmonella minnesota rough mutants," Carbohydrate Research, vol. 149, no. 2, pp. 279-291, 1986.

[65] C. H. Lee and C. M. Tsai, "Quantification of bacterial lipopolysaccharides by the purpald assay: measuring formaldehyde generated from 2-keto-3-deoxyoctonate and heptose at the inner core by periodate oxidation," Analytical Biochemistry, vol. 267, no. 1, pp. 161-168, 1999.

[66] M. Carof, S. Lebbar, and L. Szabó, "Detection of 3-deoxy2-octulosonic acid in thiobarbiturate-negative endotoxins," Carbohydrate Research, vol. 161, no. 1, pp. c4-c7, 1987.

[67] J. Kiang, S. C. Szu, L. X. Wang, M. Tang, and Y. C. Lee, "Determination of 2-keto-3-deoxyoctulosonic acid (KDO) with high- performance anion-exchange chromatography (HPAEC): survey of stability of KDO and optimal hydrolytic conditions," Analytical Biochemistry, vol. 245, no. 1, pp. 97$101,1997$. 

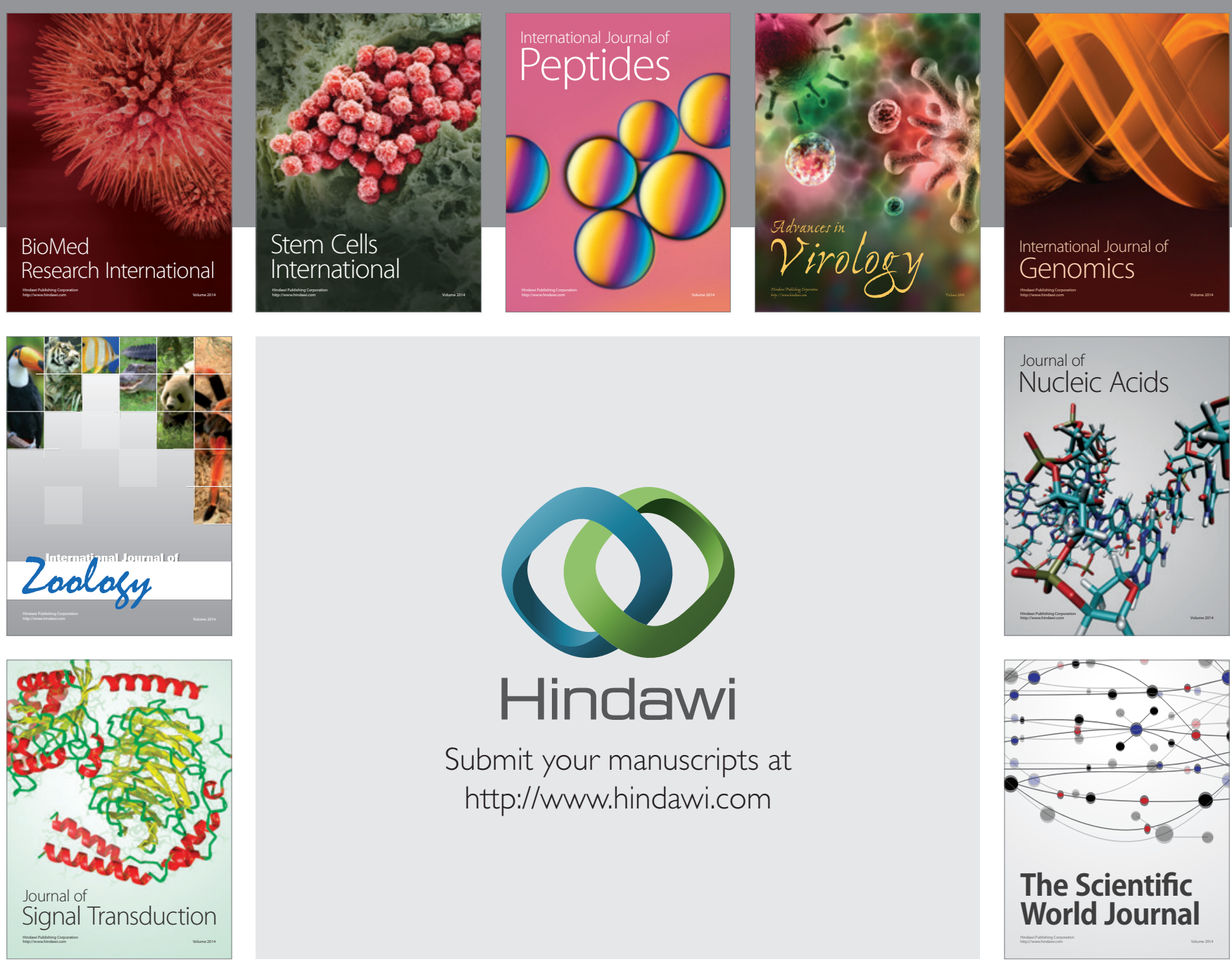

Submit your manuscripts at

http://www.hindawi.com
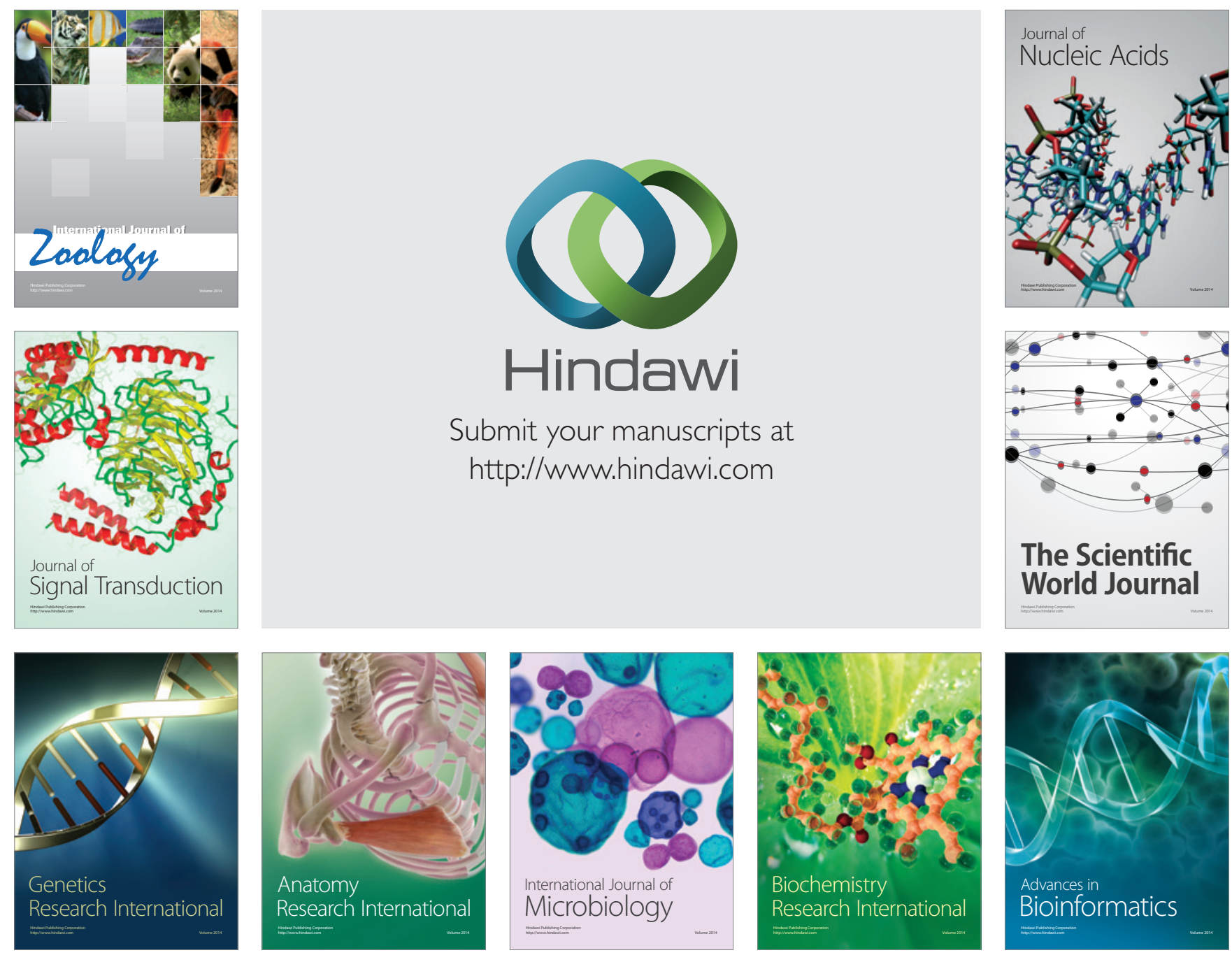

The Scientific World Journal
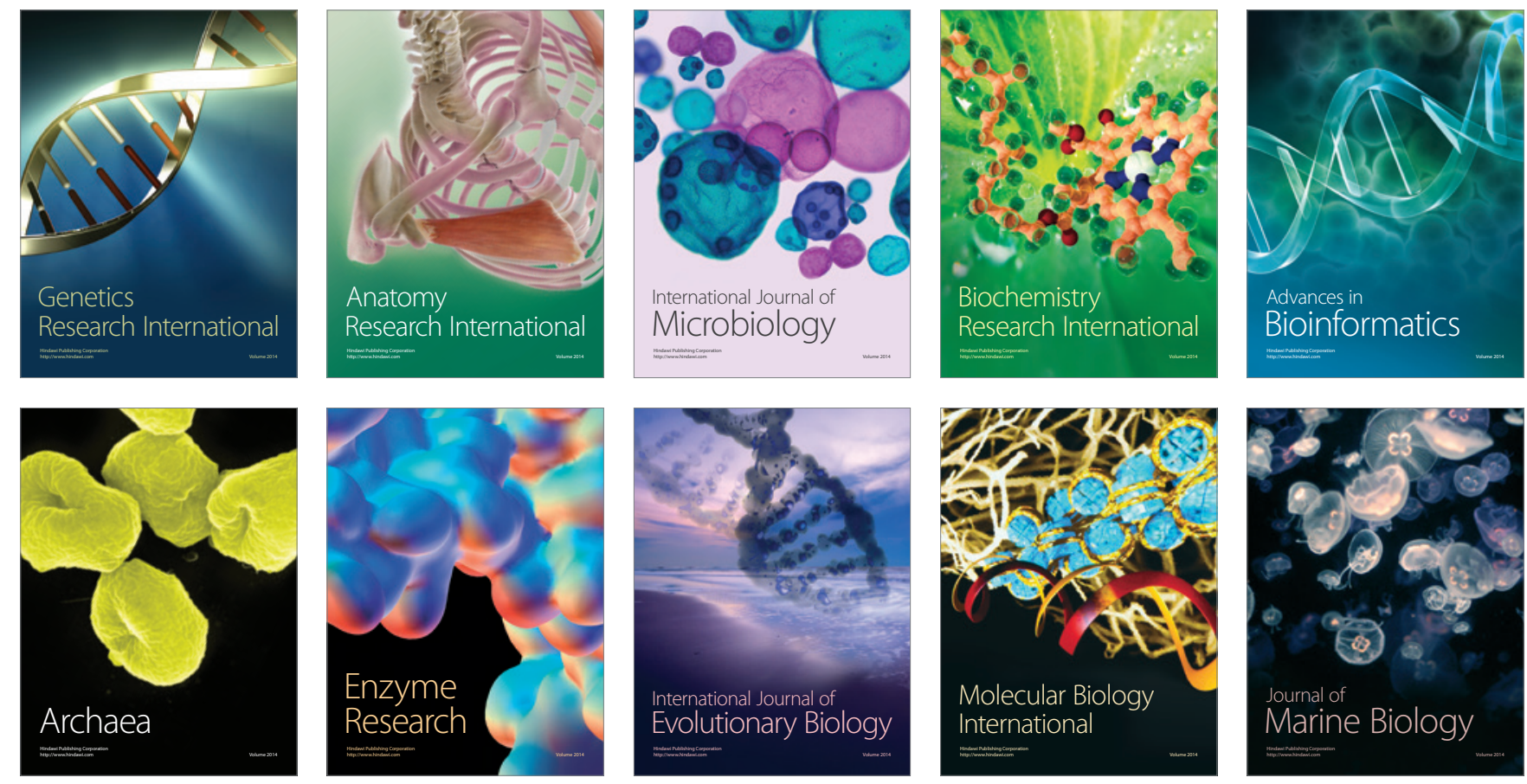